\title{
Case report: atypical presentation of vancomycin induced DRESS syndrome: a case report and review of the literature
}

\author{
Olivia Wilcox', Mohamed Hassanein ${ }^{1}$, John Armstrong ${ }^{2}$ and Nader Kassis (3* $^{*}$
}

\begin{abstract}
Background: Drug reaction with eosinophilia and systemic symptoms (DRESS) is a severe hypersensitivity drug reaction involving the skin and multiple internal organ systems. The symptoms typically present with fever and skin rash, and rapidly progress to multiple organ failures. Vancomycin is a rare drug to cause DRESS syndrome with 23 cases reported to date.

Case presentation: We described a case of a 39 year-old man who was treated with vancomycin for osteomyelitis of the foot. The patient subsequently developed acute respiratory distress syndrome (ARDS) followed by rash and acute interstitial nephritis. These symptoms were improved by withdrawal of vancomycin and a pulsed corticosteroid regimen. According to the European Registry of Severe Cutaneous Adverse Reaction Criteria (RegiSCAR) (Kardaun et al, British Journal of Dermatology, 169:1071-1080, 2013), the probability of vancomycin induced DRESS syndrome was scored as "Definite". A literature search of vancomycin induced DRESS syndrome was also performed and the overall pulmonary involvement was estimated as $5 \%$. To our knowledge, this was the first case reported with pulmonary involvement as the initial symptom.
\end{abstract}

Conclusion: This is the first case to report pulmonary manifestation as the initial symptom in vancomycin induced DRESS syndrome. Prompt recognition of this entity can expedite proper treatment and hasten recovery.

Keywords: Drug reaction, Eosinophilia, Dress, Vancomycin, Acute respiratory distress syndrome, ARDS

\section{Background}

Drug reaction with eosinophilia and systemic symptoms (DRESS) is a severe hypersensitivity drug reaction involving the skin and multiple organs. It was first described as "Dilantin syndrome" [1], and later as "Drug-induced pseudolymphoma and hypersensitivity syndrome" [2]. The term DRESS Syndrome was first proposed by Bocquet $\mathrm{H}$ et al. in 1996 [3]. Symptoms typically present with a skin rash [4], and are accompanied by fever, eosinophilia, atypical lymphocytosis, and multiple organ failures including the liver, kidneys and lungs [5]. The hallmark of DRESS is the prolonged latency, with symptoms appearing after 2 to 6 weeks from the initial drug exposure [6]. The pathogenesis is not fully understood, but is thought to be related to immunosuppression upon drug hypersensitivity reaction, and an underlying viral infection, such as human herpesvirus 6 (HHV-6). This immunosuppression may in turn lead to more severe systemic drug reaction $[5,7,8]$.

Drugs associated with DRESS syndrome include, but are not limited to, anticonvulsants, antimicrobials, antivirals, and antidepressants [6]. Vancomycin is an uncommon drug to cause DRESS syndrome, with 23 cases reported to date (Table 1). Described here is a case of vancomycin induced DRESS syndrome with an atypical presentation, which manifested initially with acute respiratory distress syndrome (ARDS), followed by rash, fever, and acute interstitial nephritis. To our knowledge, this is the first case reported with pulmonary involvement as the initial symptom.

\section{Case presentation}

A 39 year-old man presented to our institution with fever, chills, and shortness of breath for 5 days. He had a
* Correspondence: Nader.Kassis@sparrow.org
${ }^{3}$ Nephrology, Sparrow Medical Group, Lansing, MI, USA

Full list of author information is available at the end of the article (c) The Author(s). 2017 Open Access This article is distributed under the terms of the Creative Commons Attribution 4.0 International License (http://creativecommons.org/licenses/by/4.0/), which permits unrestricted use, distribution, and reproduction in any medium, provided you give appropriate credit to the original author(s) and the source, provide a link to the Creative Commons license, and indicate if changes were made. The Creative Commons Public Domain Dedication waiver (http://creativecommons.org/publicdomain/zero/1.0/) applies to the data made available in this article, unless otherwise stated. 
Table 1 Literature review of vancomycin induced DRESS syndrome

\begin{tabular}{|c|c|c|c|c|c|c|}
\hline Year & Author, Country & Age/Sex & Preceding events & Initial Symptoms & $\begin{array}{l}\text { Organ system } \\
\text { involved }\end{array}$ & $\begin{array}{l}\text { Treatment and } \\
\text { Outcome }\end{array}$ \\
\hline 1997 & Marik PE, US [22] & $51 / \mathrm{M}$ & Sepsis & Rash & Kidneys & $\begin{array}{l}\text { Corticosteroids, } \\
\text { survival }\end{array}$ \\
\hline 2005 & Yazganoğlu K, Turkey [23] & $56 / \mathrm{W}$ & $\begin{array}{l}\text { Methicillin-resistant Staphylococcus } \\
\text { aureus (MRSA) bacteremia }\end{array}$ & Fever, Rash & Liver, kidneys & $\begin{array}{l}\text { Corticosteroids, } \\
\text { survival }\end{array}$ \\
\hline 2005 & Zuliani E, Switzerland [24] & $41 / \mathrm{W}$ & Bacterial endocarditis & Rash, Fever & Kidneys, liver & $\begin{array}{l}\text { Corticosteroids and } \\
\text { cyclosporine, survival }\end{array}$ \\
\hline 2006 & Kwon H-S, Korea [25] & $50 / \mathrm{M}$ & Vertebral osteomyelitis & Rash, fever & Kidneys & $\begin{array}{l}\text { Corticosteroids, } \\
\text { survival }\end{array}$ \\
\hline 2007 & Tamagawa-Mineoka R, Japan [26] & $52 / \mathrm{W}$ & MRSA, ear surgery & Rash, fever & Liver, kidneys & $\begin{array}{l}\text { Pulsed Corticosteroids, } \\
\text { survival }\end{array}$ \\
\hline 2008 & Vauthey L, Switzerland [27] & $60 / \mathrm{W}$ & MRSA, leg amputation & $\begin{array}{l}\text { Rash, fever, } \\
\text { periorbital edema }\end{array}$ & Liver & $\begin{array}{l}\text { Corticosteroids, } \\
\text { survival }\end{array}$ \\
\hline 2009 & Mennicke M, Switzerland [28] & $60 / M$ & Staphylococcus aureus bacteremia & Fever, rash & Liver & $\begin{array}{l}\text { Patient deceased after } \\
\text { liver transplantation }\end{array}$ \\
\hline 2010 & Vinson AE, US [29] & $14 / \mathrm{M}$ & Spinal surgery infection & $\begin{array}{l}\text { Fever, Rash, } \\
\text { vomiting }\end{array}$ & Liver & $\begin{array}{l}\text { Corticosteroids, } \\
\text { survival }\end{array}$ \\
\hline 2011 & O'Meara P, Canada [30] & $60 / M$ & MRSA, pelvic surgery & Rash & $\begin{array}{l}\text { Liver, kidneys, } \\
\text { Lungs }\end{array}$ & $\begin{array}{l}\text { Corticosteroids, } \\
\text { survival }\end{array}$ \\
\hline 2012 & Blumenthal KG, US [31] & $65 / M$ & $\begin{array}{l}\text { Hemolytic Group B Streptococcus } \\
\text { empyema, Esophageal perforation }\end{array}$ & Rash & $\begin{array}{l}\text { Liver, kidneys, } \\
\text { Lungs }\end{array}$ & $\begin{array}{l}\text { Corticosteroids, } \\
\text { survival }\end{array}$ \\
\hline 2012 & Blumenthal KG, US [31] & $40 / M$ & $\begin{array}{l}\text { Propionibacterium and Peptostreptococcus, } \\
\text { prosthetic shoulder }\end{array}$ & Fever, Rash & Liver, kidneys & $\begin{array}{l}\text { Corticosteroids, } \\
\text { survival }\end{array}$ \\
\hline 2012 & Blumenthal KG, US [31] & $48 / \mathrm{W}$ & $\begin{array}{l}\text { Coagulase-negative Staphylococcus, } \\
\text { shoulder surgery }\end{array}$ & Rash & $\begin{array}{l}\text { Liver, } \\
\text { gastrointestinal } \\
\text { track }\end{array}$ & $\begin{array}{l}\text { Treatment and } \\
\text { outcome not } \\
\text { clearly mentioned. }\end{array}$ \\
\hline 2012 & Blumenthal KG, US [31] & $74 / \mathrm{M}$ & Hand trauma & Rash & Liver & $\begin{array}{l}\text { Treatment and } \\
\text { outcome not } \\
\text { clearly mentioned. }\end{array}$ \\
\hline 2012 & Blumenthal KG, US [31] & $51 / \mathrm{M}$ & Osteomyelitis of the finger & Rash, fever & Liver & $\begin{array}{l}\text { Corticosteroids, } \\
\text { survival }\end{array}$ \\
\hline 2012 & Díaz-Mancebo R, Spain [32] & $74 / \mathrm{W}$ & $\begin{array}{l}\text { Staphylococcus epidermidis, } \\
\text { spondylodiscitis }\end{array}$ & Rash, Renal injury & $\begin{array}{l}\text { Kidneys, liver, } \\
\text { lungs }\end{array}$ & $\begin{array}{l}\text { Pulsed corticosteroids, } \\
\text { survival }\end{array}$ \\
\hline 2014 & Young S, Australia [33] & 24/M & Corynebacterium jeikeium, septic arthritis & Rash & Liver & $\begin{array}{l}\text { Corticosteroids, } \\
\text { survival }\end{array}$ \\
\hline 2014 & Young S, Australia [33] & $48 / \mathrm{W}$ & Osteomyelitis & $\begin{array}{l}\text { Rash, hepatic } \\
\text { injury }\end{array}$ & Liver & $\begin{array}{l}\text { Corticosteroids, } \\
\text { survival }\end{array}$ \\
\hline 2014 & Young S, Australia [33] & $59 / M$ & MRSA, wound infection & Rash & Liver & $\begin{array}{l}\text { Corticosteroids, } \\
\text { survival }\end{array}$ \\
\hline 2015 & Güner MD, Turkey [34] & $73 / \mathrm{M}$ & Infected left hip prosthesis & Fever & Kidneys & $\begin{array}{l}\text { Corticosteroids, } \\
\text { survival }\end{array}$ \\
\hline 2015 & Güner MD, Turkey [34] & $72 / \mathrm{W}$ & Infected left knee prosthesis & Fever & Kidneys, liver & $\begin{array}{l}\text { Corticosteroids, } \\
\text { survival }\end{array}$ \\
\hline 2016 & Kim KM, Japan [35] & $11 / \mathrm{M}$ & Parotitis & Rash, proteinuria & Kidneys & $\begin{array}{l}\text { Corticosteroids, } \\
\text { survival }\end{array}$ \\
\hline 2016 & Miyazu D, Japan [36] & 79/M & MRSA, femur fracture & Rash, fever & Lung & $\begin{array}{l}\text { Corticosteroids, } \\
\text { survival }\end{array}$ \\
\hline 2016 & Webb PS, UK [37] & $73 / M$ & Septic shock & Fever, rash & Kidneys, heart & $\begin{array}{l}\text { Corticosteroids, } \\
\text { survival }\end{array}$ \\
\hline
\end{tabular}

past medical history of type I diabetes, seizures, and hyperlipidemia. His home medications included atorvastatin, insulin, lamotrigine and pregabalin. He had allergy to cephalexin, with itchiness as the only allergic symptom. He also had a right calcaneus fracture with open reduction internal fixation, and he was recently diagnosed with osteomyelitis of the right calcaneus. He was started with parenteral vancomycin 3 weeks prior to admission. On physical exam at admission, he was noted to be febrile $\left(102.6^{\circ} \mathrm{F}\right)$, with severe shortness of breath. 
There was no evidence of rash, renal injury, lymphadenopathy or hepatosplenomegaly. Chest $\mathrm{x}$-ray in the emergency department (ED) revealed a mild left lower lobe airspace opacity (Fig. 1a). He was placed on vancomycin and levofloxacin, and was admitted for possible community acquired pneumonia. At admission, his laboratory tests, however, were not suggestive of infection, with Leukocyte count 6700/ $\mathrm{mm}^{3}$ (Neutrophils: $72.1 \%$, Lymphocytes: $15.4 \%$, Monocytes: 7.9\%, Eosinophils: 4\%, Basophils: $0.6 \%$ ), Absolute eosinophil count 270/uL (within normal range), Lactate 1.0, and with only mildly elevated C-reactive protein 3.4 (CRP) $(0.0-1.0 \mathrm{mg} / \mathrm{dL})$, and mildly elevated Sedimentation rate (SED) $20(0-15 \mathrm{~mm} / \mathrm{h})$. Orthopedics was also consulted in the ED and determined that his osteomyelitis was controlled and localized, with no acute intervention needed.

Hospital day 2-3: He developed ARDS with preintubation $\mathrm{PaO} 2 / \mathrm{FiO} 2$ ratio $82(100 \% \mathrm{FiO} 2)$ and postintubation $\mathrm{PaO} 2 / \mathrm{FiO} 2$ ratio 109 (70\% $\mathrm{FiO} 2$ and PEEP of $10 \mathrm{~cm} \mathrm{H20)}$ (Fig. 1b). He was placed on vancomycin, piperacillin - tazobactam and levofloxacin for possible sepsis. $10-20 \mathrm{ml}$ bronchoalveolar lavage (BAL) fluid was obtained via bronchoscopy and revealed serosanguineous fluid with 10-15 white blood cell per high power field and with no organisms identified. Polymerase chain reaction test was obtained via nasopharyngeal swab and was negative for Influenza and Respiratory Syncytial Virus. Blood culture was negative for organisms. There was a questionable convulsion episode witnessed by the family and he was started on levetiracetam due to a history of seizure. An echocardiogram was performed and indicated normal cardiac function (ejection fraction $60 \%$ ) and normal right ventricular diastolic pressure
(36.8 $\mathrm{mmHg}$ ). Day 4-5: he developed new onset acute renal injury (AKI) and new morbilliform rash in bilateral hands and knees; vancomycin, piperacillin - tazobactam and levofloxacin were discontinued, and meropenem and daptomycin were started. Day 6-11: the rash progressed to the entire body (sparing face) and became indurated with associated edema (Fig. 1c, d); new onset eosinophilia occurred with a peak of 4000/uL; fever and leukocytosis persisted despite treatment with antibiotics. AKI workup indicated interstitial nephritis primarily based on positive urine eosinophil (7\%), and negative autoimmune workup including Myeloperoxidase Antibody $(<0.2)$, Proteinase 3 Antibody $(<0.2)$, Antinuclear Antibody (negative), C3 complement 115 (77-166), and C4 complement 34 (18-52); Urine protein to creatinine ratio was 0.66 (normal). Lumbar puncture and magnetic resonance imaging of the brain excluded bacterial meningitis, Cryptococcus, Varicella Zoster Virus, Herpes Simplex I/II and Toxoplasmosis. Computed tomography of the abdomen and pelvis revealed no intra-abdominal infectious source. A skin biopsy showed perivascular lymphocytes, occasional neutrophils, scattered eosinophils, and the absence of intraluminal microthrombi (Fig. 1e, f). Day 12-14: patient continued to be in critical condition with persistent fever, leukocytosis and negative infection workup. The decision was made to treat as DRESS syndrome with a pulsed corticosteroid regimen, methylprednisolone $125 \mathrm{mg}$ (approximately $1.25 \mathrm{mg} / \mathrm{kg}$ daily, body weight $99.3 \mathrm{~kg}$ ) for 3 days. The patient responded well. He had resolution of the fever, and clinical improvement of ventilation. His renal function recovered in 2 days, and the diffuse rash was reduced to
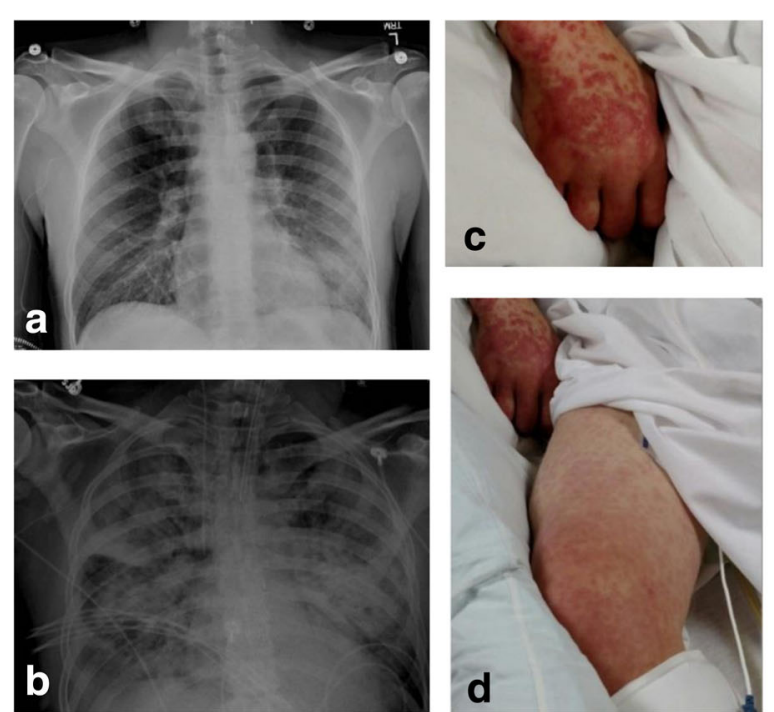
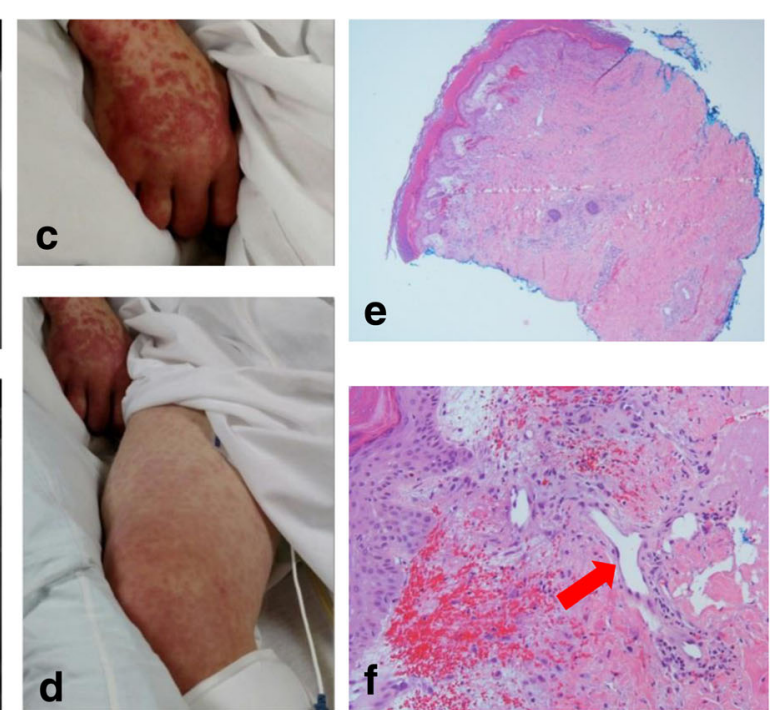

Fig. 1 Clinical and imaging manifestation of the case. a Chest X-Ray on day 1 showing mild left lower lobe airspace opacity; b Chest X-Ray on day 3 showing diffuse pulmonary infiltrate; $\mathbf{c} \& \mathbf{d}$ Diffuse rash on day 8 ; e $3 \mathrm{~mm}$ punch biopsy of the dorsum of the right hand; $\mathbf{f}$ Absence of fibrin and microthrombi deposition in the vessel lumen (arrow) 
trace erythema in 5 days. The response to the corticosteroids is illustrated Fig. 2 in further details. He was treated with tapering oral prednisone for additional 2 weeks, and was discharged to inpatient rehabilitation facility, and then home. A three-month phone follow up revealed independent daily living skills and improved exercise tolerance. A time table of the hospital course can be found in the Additional file 1 .

\section{Discussion and conclusions}

DRESS syndrome is a dermatological emergency with mortality approximately 10\% [9]. It has an estimated incidence ranging between 1 in 1000 and 1 in 10,000 drug exposures $[3,10]$. The pathogenesis of DRESS syndrome is not well understood, but is hypothesized to be an immunological reaction with possible viral involvement [11]. It is associated with decreasing circulating B cells and serum immunoglobulin level at the early stage of the disease [11]. This immunosuppression may lead to viral reactivations, such as from HHV-6, which may in turn lead to more severe systemic immune reaction. DRESS is also associated elevation of inflammatory cytokines during the course of the disease, in particular, Interleukin 5 has been reported to peak several days before the peak of eosinophilia [12]. We speculate that these inflammatory cytokines may have contributed to the organ injury, and subsequently promoted eosinophilia.

Due to the variability of clinical presentation of DRESS, a scoring system, the European Registry of Severe Cutaneous Adverse Reaction Criteria (RegiSCAR), was proposed to aid diagnosis [13]. The patient scored seven points according to the RegiSCAR criteria, including fever (one point), eosinophilia greater than $1500 / \mathrm{uL}$ (two points), skin involvement and biopsy suggesting drug eruption (two points), renal and lung involvements (two points), and negative testing for ANA, blood culture and hepatitis. This score categorized the probability of vancomycin induced DRESS syndrome as "Definite".

We also considered other diagnoses involving hypereosinophilia and multiple organ failures. Eosinophilic Granulomatosis with Polyangiitis (EGPA), previously Churg-Strauss, is a necrotizing vasculitis associated with severe asthma and eosinophilia [14]. Features of EGPA include elevated Antineutrophil Cytoplasm Antibody (ANCA) $(30-70 \%$ cases), tissue eosinophilia in BAL fluid, and intraluminal microthrombi and fibrinoid necrosis in skin biopsy $[14,15]$. The patient had negative ANCA, absence of eosinophils in the BAL fluid, and absence of intraluminal microthrombi in skin biopsy, making EGPA a less likely option. Hypereosinophilic syndrome (HES) is another entity which overlaps with DRESS. Secondary HES has a broad range of causes including parasitic infection, allergy and drug reactions. DRESS is currently classified as a subtype of drug induced HES [16]. Alternatively, primary HES is a myeloproliferative disorder and involves neoplastic eosinophils with cytogenetic abnormalities [16]. The peripheral blood smear of the patient did not demonstrate any lymphoid or myeloid lineage dysplasia that may be suggestive of primary HES. Stevens Johnson Syndrome and Toxic Epidermal Necrolysis (SIS/TEN) is a spectrum of severe drug reaction and features epidermal necrosis with epidermis detachment of at least $10 \%$ of body surface [17]. The rash in this case did not involve any bullae, desquamative or erosive lesions, and its appearance was not suggestive of SJS/TEN. Kawasaki disease is

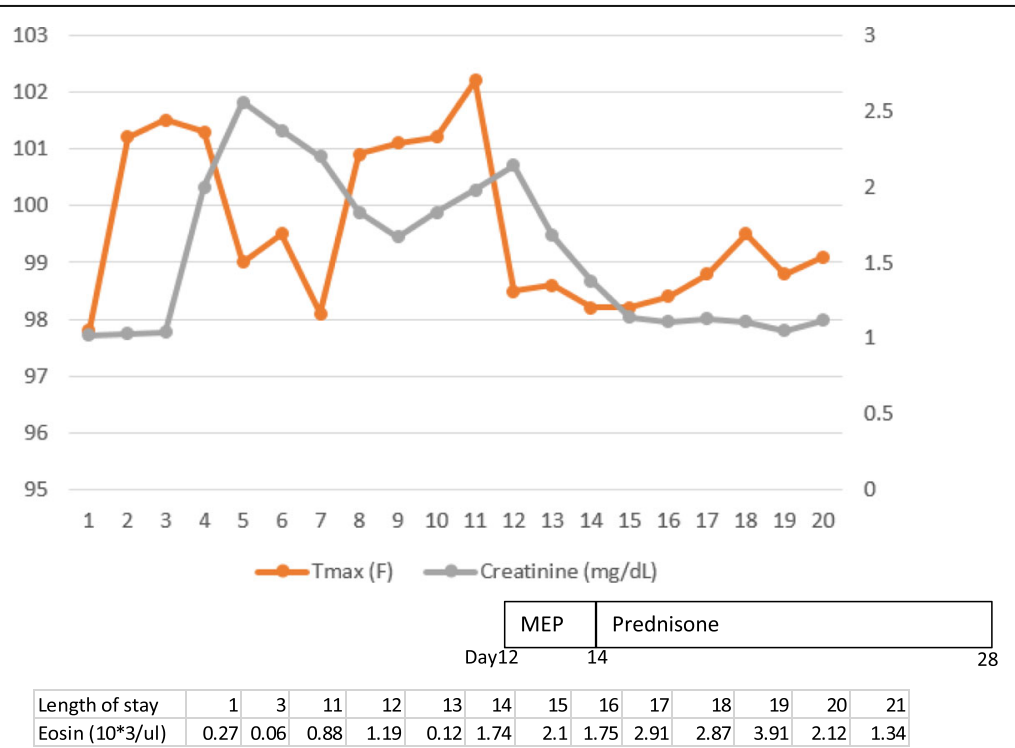

Fig. 2 Laboratory data and response to corticosteroid treatment. Tmax - temperature maximum; Eosin - eosinophils; MEP - Methylprednisolone 
another condition characterized with fever, rash and systemic organ involvement. Kawasaki disease has well defined criteria including polymorphic rash, conjuctival changes and lymphadenopathy, which are not present in this case [18].

Vancomycin is a glycopeptide antibiotic with a half-life of 6 to 10 days [19]. It has activity against many grampositive bacteria, and the gram-negative bacteria in the genus of Flavobacterium [19]. In the past few decades, due to the increasing prevalence of Methicillin-resistant Staphylococcus aureus (MRSA), parenteral vancomycin has been established for treating a variety of infections including sepsis, pneumonia, cellulitis, endocarditis and meningitis [20, 21]. Significant hypersensitivity reactions from vancomycin have been reported, including Linear IgA Bullous Dermatosis, DRESS, SJS/TEN [20]. We performed a literature search and identified 23 cases of vancomycin induced DRESS syndrome (Table 1) [22-37]. In addition, there are two articles in French and one article in German, which are not included in the discussion here. It is rare to involve pulmonary system and Miyazu D et al. have estimated pulmonary involvement to be 5\% [36]. There are four cases reported to involve the pulmonary system and our case is the first one that presented with acute respiratory failure as the initial symptom [30-32, 36].

The mainstay of treatment for DRESS syndrome is withdrawal of the offending medication and treatment with corticosteroid. Due to vancomycin's prolonged halflife, severe refractory cases may benefit from dialysis. One session of hemodialysis may remove up to $50 \%$ of plasma concentration of vancomycin [19]. A stepwise algorithm was proposed to treat DRESS syndrome with parenteral corticosteroid until resolution of fever and rash followed by oral corticosteroid for 4 to 6 weeks [38]. Rapid taper of corticosteroid can result in reoccurrence of symptoms and prolonged hospital stay [33]. A pulsed corticosteroid treatment has been suggested as an alternative treatment regimen, possibly due to decreased side effect [32]. We achieved prompt recovery with pulsed methylprednisolone at $1.25 \mathrm{mg} / \mathrm{kg}$ daily for 3 days. Higher doses of corticosteroids were also reported, including methylprednisolone $250 \mathrm{mg}$ daily [32], and $500 \mathrm{mg}$ daily [26], for 3 days. Higher dose of corticosteroids may be associated with an increased risk of agitation and difficulty weaning ventilation in intubated patient. Numerous long-term sequelae of DRESS syndrome has been reported, including infections, thyroiditis, type I diabetes, and acute interstitial nephritis [39].

In conclusion, this is the first case to report pulmonary manifestation as the initial symptom in vancomycin induced DRESS syndrome. Prompt recognition of this entity can expedite proper treatment and hasten recovery.

\section{Additional file}

Additional file 1: Time table - Flow diagram - Flow diagram of important events during the hospital stay. (DOCX $52 \mathrm{~kb}$ )

\section{Abbreviations \\ AKI: Acute renal injury; ANCA: Antineutrophil Cytoplasm Antibody; ARDS: Acute respiratory distress syndrome; BAL: Bronchoalveolar lavage; DRESS: Drug reaction with eosinophilia and systemic symptoms; \\ EGPA: Eosinophilic Granulomatosis with Polyangiitis; HES: Hypereosinophilic syndrome; HHV-6: Human Herpesvirus 6; MRSA: Methicillin-resistant Staphylococcus aureus; RegiSCAR: European Registry of Severe Cutaneous Adverse Reaction Criteria}

\section{Acknowledgements}

The authors thank Dr. Ying Qin for providing the pathology slides and interpretation of the result.

\section{Funding}

Not applicable

\section{Availability of data and materials}

All data are available in the manuscript [and its supplementary information files]

\section{Authors' contributions}

OW analyzed, interpreted the patient data, performed the literature review and drafted the manuscript. MH performed the literature review and participated the drafting of the manuscript. JA and NKA participated in data interpretation and critically revised the manuscript. All authors read and approved the final manuscript.

Ethics approval and consent to participate

Not applicable

\section{Consent for publication}

A written informed consent was obtain from the patient for publication of identifying data.

\section{Competing interests}

The authors declare that they have no competing interests.

\section{Publisher's Note}

Springer Nature remains neutral with regard to jurisdictional claims in published maps and institutional affiliations.

\section{Author details}

${ }^{1}$ Department of Internal Medicine, Michigan State University, East Lansing, MI, USA. ²Pulmonary Critical Care, Sparrow Medical Group, Lansing, MI, USA. ${ }^{3}$ Nephrology, Sparrow Medical Group, Lansing, MI, USA.

Received: 1 December 2017 Accepted: 15 December 2017 Published online: 28 December 2017

\section{References}

1. Chaiken BH, Goldberg BI, Segal JP. Dilantin sensitivity: report of a case of hepatitis with jaundice, pyrexia and exfoliative dermatitis. N Engl J Med. 1950;242(23):897-8.

2. Saltzstein SL, Ackerman LV. Lymphadenopathy induced by anticonvulsant drugs and mimicking clinically and pathologically malignant lymphomas. Cancer. 1959;12(1):164-82

3. Bocquet $\mathrm{H}$, Bagot M, Roujeau JC. Drug-induced pseudolymphoma and drug hypersensitivity syndrome (drug rash with Eosinophilia and systemic symptoms: DRESS). In: Seminars in cutaneous medicine and surgery: 1996: WB Saunders; 1996. p. 250-7.

4. Cardoso CS, Vieira AM, Oliveira AP. DRESS syndrome: a case report and literature review. BMJ case reports. 2011;2011:bcr0220113898.

5. Chen Y-C, Cho Y-T, Chang C-Y, Chu C-Y. Drug reaction with eosinophilia and systemic symptoms: a drug-induced hypersensitivity syndrome with variable clinical features. Dermatol Sin. 2013;31(4):196-204. 
6. Husain Z, Reddy BY, Schwartz RA. DRESS syndrome: part I. Clinical perspectives. J Am Acad Dermatol. 2013;68(5):693. e691-14.

7. Shiohara T, Inaoka M, Kano Y. Drug-induced hypersensitivity syndrome (DIHS): a reaction induced by a complex interplay among herpesviruses and antiviral and antidrug immune responses. Allergol Int. 2006;55(1):1-8.

8. Suzuki $Y$, Inagi R, Aono T, Yamanishi K, Shiohara T. Human herpesvirus 6 infection as a risk factor for the development of severe drug-induced hypersensitivity syndrome. Arch Dermatol. 1998;134(9):1108-12.

9. Chen Y-C, Chiu H-C, Chu C-Y. Drug reaction with eosinophilia and systemic symptoms: a retrospective study of 60 cases. Arch Dermatol. 2010;146(12):1373-9.

10. Chiou CC, Yang LC, Hung SI, Chang YC, Kuo TT, Ho HC, Hu S, Hong HS, Chung WH. Clinicopathlogical features and prognosis of drug rash with eosinophilia and systemic symptoms: a study of 30 cases in Taiwan. J Eur Acad Dermatol Venereol. 2008:22(9):1044-9.

11. Hirahara K, Kano Y, Mitsuyama Y, Takahashi R, Kimishima M, Shiohara T. Differences in immunological alterations and underlying viral infections in two well-defined severe drug eruptions. Clin Exp Dermatol. 2010;35(8):863-8.

12. Choquet-Kastylevsky G, Intrator L, Chenal C, Bocquet H, Revuz J, Roujeau J. Increased levels of interleukin 5 are associated with the generation of eosinophilia in drug-induced hypersensitivity syndrome. Br J Dermatol. 1998;139(6):1026-32.

13. Kardaun S, Sekula P, Valeyrie-Allanore L, Liss Y, Chu C, Creamer D, Sidoroff A, Naldi L, Mockenhaupt M, Roujeau J. Drug reaction with eosinophilia and systemic symptoms (DRESS): an original multisystem adverse drug reaction. Results from the prospective RegiSCAR study. $\mathrm{Br}$ J Dermatol. 2013;169(5):1071-80.

14. Groh M, Pagnoux C, Baldini C, Bel E, Bottero P, Cottin V, Dalhoff K, Dunogué B, Gross W, Holle J. Eosinophilic granulomatosis with polyangiitis (ChurgStrauss)(EGPA) consensus task force recommendations for evaluation and management. European journal of internal medicine. 2015;26(7):545-53.

15. Carlson JA. The histological assessment of cutaneous vasculitis. Histopathology. 2010;56(1):3-23.

16. Gotlib J. World Health Organization-defined eosinophilic disorders: 2017 update on diagnosis, risk stratification, and management. Am J Hematol. 2017:92(11):1243-59.

17. Schneider JA, Cohen PR. Stevens-Johnson syndrome and toxic epidermal Necrolysis: a concise review with a comprehensive summary of therapeutic interventions emphasizing supportive measures. Adv Ther. 2017;34(6):1235-44.

18. Denby KJ, Clark DE, Markham LW. Management of Kawasaki disease in adults. Heart. 2017; heartjnl-2017-311774

19. Deck D, Winston L. Chapter 43. Beta-Lactam \& Other Cell Wall-\& membraneactive antibiotics. In: Basic \& clinical pharmacology. 12th ed. New York: McGraw-Hill; 2012

20. Minhas JS, Wickner PG, Long AA, Banerji A, Blumenthal KG. Immunemediated reactions to vancomycin: a systematic case review and analysis. Ann Allergy Asthma Immunol. 2016;116(6):544-53.

21. Korman T, Turnidge J, Grayson M. Vancomycin vintage: my favourite DRESS. Intern Med J. 2015;45(2):233-4.

22. Marik PE, Ferris N. Delayed hypersensitivity reaction to vancomycin. Pharmacotherapy: The Journal of Human Pharmacology and Drug Therapy. 1997;17(6):1341-4.

23. Yazganoǧlu K, Özkaya E, Ergin-Özcan P, Cakar N. Vancomycin-induced drug hypersensitivity syndrome. J Eur Acad Dermatol Venereol. 2005;19(5):648-50.

24. Zuliani E, Zwahlen H, Gullet F, Marone C. Vancomycin-induced hypersensitivity reaction with acute renal failure: resolution following cyclosporine treatment. Clin Nephrol. 2005;64(2)

25. Kwon H-S, Chang Y-S, Jeong Y-Y, Lee S-M, Song W-J, Kim H-B, Kim Y-K, Cho $\mathrm{S}-\mathrm{H}, \mathrm{Kim} \mathrm{Y}-\mathrm{Y}$, Min K-U. A case of hypersensitivity syndrome to both vancomycin and teicoplanin. J Korean Med Sci. 2006;21(6):1108-10.

26. Tamagawa-Mineoka R, Katoh N, Nara T, Nishimura Y, Yamamoto S, Kishimoto S. DRESS syndrome caused by teicoplanin and vancomycin, associated with reactivation of human herpesvirus-6. Int J Dermatol. 2007; 46(6):654-5

27. Vauthey L, Uçkay I, Abrassart S, Bernard L, Assal M, Ferry T, Djordjevic M, Roussos C, Vaudaux P. Vancomycin-induced DRESS Syndrome in a female patient. Pharmacology. 2008;82(2):138-41.

28. Mennicke M, Zawodniak A, Keller M, Wilkens L, Yawalkar N, Stickel F, Keogh A, Inderbitzin D, Candinas D, Pichler WJ. Fulminant liver failure after
Vancomycin in a Sulfasalazine-induced DRESS syndrome: fatal recurrence after liver transplantation. Am J Transplant. 2009;9(9):2197-202.

29. Vinson AE, Dufort EM, Willis MD, Eberson CP, Harwell J. Drug rash, eosinophilia, and systemic symptoms syndrome: two pediatric cases demonstrating the range of severity in presentation - a case of vancomycin-induced drug hypersensitivity mimicking toxic shock syndrome and a milder case induced by minocycline. Pediatr Crit Care Med. 2010; 11(4):e38-43.

30. O'Meara P, Borici-Mazi R, Morton AR, Ellis AK. DRESS with delayed onset acute interstitial nephritis and profound refractory eosinophilia secondary to Vancomycin. Allergy, Asthma Clin Immunol. 2011;7(1):16.

31. Blumenthal KG, Patil SU, Long AA. The importance of vancomycin in drug rash with eosinophilia and systemic symptoms (DRESS) syndrome. In: Allergy and asthma proceedings: 2012: OceanSide Publications, Inc; 2012. p. $165-71$.

32. Díaz-Mancebo R, Costero-Fernández O, Vega-Cabrera C, Olea-Tejero T, Yébenes L, Picazo ML, Selgas-Gutiérrez R. Dress syndrome and acute tubulointerstitial nephritis after treatment with vancomycin and betalactams. Case report and literature review. Nefrologia. 2012;32(5):685-7.

33. Young S, Ojaimi S, Dunckley H, Douglas M, Kok J, Fulcher D, Lin MW, Swaminathan S. Vancomycin associated drug reaction with eosinophilia and systemic symptoms syndrome. Intern Med J. 2014:44(7):694-6.

34. Güner MD, Tuncbilek S, Akan B, Caliskan-Kartal A. Two cases with HSS/ DRESS syndrome developing after prosthetic joint surgery: does vancomycin-laden bone cement play a role in this syndrome? BMJ case reports. 2015;2015:bcr2014207028.

35. Kim KM, Sung K, Yang HK, Kim SH, Kim HY, Ban GH, Park SE, Lee HD, Kim SY. Acute tubular necrosis as a part of vancomycin induced drug rash with eosinophilia and systemic symptoms syndrome with coincident postinfectious glomerulonephritis. Korean journal of pediatrics. 2016:59(3):145-8.

36. Miyazu D, Kodama N, Yamashita D, Tanaka H, Inoue S, Imakyure O, Hirakawa $M$, Shuto $H$, Kataoka Y. DRESS syndrome caused by cross-reactivity between Vancomycin and subsequent Teicoplanin administration: a case report. The American journal of case reports. 2016;17:625.

37. Webb PS, Al-Mohammad A. Enigma: infection or allergy? Vancomycininduced DRESS syndrome with dialysis-dependent renal failure and cardiac arrest. BMJ case reports. 2016;2016:bcr2016215911.

38. Sultan SJ, Sameem F, Ashraf M. Drug reaction with eosinophilia and systemic symptoms: manifestations, treatment, and outcome in 17 patients. Int J Dermatol. 2015;54(5):537-42.

39. Kano $Y$, Tohyama $M$, Aihara M, Matsukura $S$, Watanabe $H$, Sueki $H$, lijima $M$, Morita E, Niihara $H$, Asada H. Sequelae in 145 patients with drug-induced hypersensitivity syndrome/drug reaction with eosinophilia and systemic symptoms: survey conducted by the Asian research committee on severe Cutaneous adverse reactions (ASCAR). J Dermatol. 2015:42(3):276-82.

\section{Submit your next manuscript to BioMed Central and we will help you at every step:}

- We accept pre-submission inquiries

- Our selector tool helps you to find the most relevant journal

- We provide round the clock customer support

- Convenient online submission

- Thorough peer review

- Inclusion in PubMed and all major indexing services

- Maximum visibility for your research

Submit your manuscript at www.biomedcentral.com/submit 